\author{
Научная статья \\ УДК 165.62
}

DOI: $10.18101 / 1994-0866-2021-1-64-70$

\title{
ФЕНОМЕНОЛОГИЧЕСКОЕ ОСМЫСЛЕНИЕ ФИЛОСОФСКОЙ ЛИРИКИ
}

\author{
(C) Тимощук Елена Андреевна \\ кандидат философских наук, доцент, \\ Высшая школа государственного управления РАНХиГС \\ Россия, 119571, г. Москва, пр. Вернадского, 82 \\ e@timos.elcom.ru
}

\begin{abstract}
Аннотация. Традиционно считается, что философия как академическая дисциплина тяготеет к рациональному осмыслению действительности. Однако многие философские вопросы выходят за рамки рационального познания. Многие философские концепции развиваются из эмоционального потрясения, острого переживания, чувствования отдельных аспектов бытия. Таковы философские рубаи О. Хайама, поэзия Гете, произведения Достоевского, эссе Ницше. В период жесткой рационализации повседневности, требований наукометрии гуманитарных дисциплин целесообразно обогатить преподавание философии эстетическим компонентом (философской лирикой). Феноменологическая традиция Романа Ингардена задает параметры исследования литературного произведения. Феноменологический инструментарий (многослойность, интенциональность, эпохе́, жизненный мир) позволяет осмыслить тексты, вынося за скобки восприятия наслоения культурного опыта. Обращение к философскому чувству как к острому переживанию общекатегориальных вопросов дополнит преподавание философии, а феноменологический метод анализа лирического текста поможет развить личностное восприятие философской проблематики.
\end{abstract}

Ключевые слова: философская лирика; чувство; предмет философии; феноменологический метод; многослойность; эпохе.

\section{Для цитирования}

Тимощук Е. А. Феноменологическое осмысление философской лирики // Вестник Бурятского государственного университета. Философия. 2021. Вып. 1. С. 64-70.

Философию принято ассоциировать с разумным началом. Энциклопедический словарь указывает, что «философия является теоретическим ядром мировоззрения. Она стремится рациональными средствами создать предельно обобщенную картину мира и места человека в нем» [1]. Со времен античности философия развивалась как логико-теоретическая форма мировоззрения, хотя именно этот способ рефлексии не укладывается в единые, четко оформленные рамки. Вполне справедливым видится заключение Б. Рассела о том, что «философия...является чем-то промежуточным между теологией и наукой. Подобно теологии, она состоит в спекуляциях по поводу предметов, относительно которых точное значение оказывалось до сих пор недостижимым; но подобно науке, она взывает скорее к человеческому разуму, чем к авторитету, будь то авторитет традиции или откровения. Все точное знание, по моему мнению, принадлежит 
науке; все догмы, поскольку они превышают точное знание, принадлежат теологии. Но между теологией и наукой имеется Ничья Земля, подвергающаяся атакам с обеих сторон; эта Ничья Земля и есть философия» [2, с. 7]. Такая оценка отражает и диахронное состояние философии, с ее неизбежным противостоянием рациональных форм познания и интуитивного поиска, предчувствования, эмоциональной вовлеченности в предмет философствования, и синхронный эпистемологический кризис современной философии. Можно сказать, что философия изначально балансировала на грани этих форм рефлексии: «...мудрость есть знание и интуиция наиболее ценных по своей природе вещей. Они (философы) знают нечто исключительное, изумительное, трудное и божественное...» ${ }^{1}$. Философия не только начинается удивлением, кульминация классической философии также пронизана этим чувством. На это указывает М. Эпштейн в открытой лекции «О призвании философии» (прочитана 2 апреля 2013 г. в библиотеке «Дом А. Ф. Лосева», Москва, Арбат, 33), вспоминая знаменитое высказывание И. Канта: «Две вещи наполняют душу всегда новым и все более сильным удивлением $и$ благоговением, чем чаще и продолжительнее мы размышляем о них, - это звездное небо надо мной и моральный закон во мне» [3, с. 439]. Полагаю, что без эмоционального компонента, без удивления и благоговения перед исключительным, трудным для восприятия любая наука, а философия прежде всего, лишится перспективы, будет одномерна и слишком отчуждена от культуры. Многие философские произведения имеют несомненную художественную ценность и могут рассматриваться как самостоятельные произведения искусства. Тексты, в которых авторы затрагивают вопросы философского характера, заслуживают внимания при изучении философии. Образцы «лирической философии»: отдельные эссе Ницше, Кьеркегора, Камю, Сартра, «Исповедь» А. Аврелия, фрагменты романов Достоевского, еще находят свое место в преподавании философии, а произведения «лирической философии»: рубаи Омара Хайаяма, стихи И. Гете, Р. Рильке, поэзия Серебряного века, остаются за границами курса. Вызывает опасение целенаправленное пропедевтическое сближение философии и эпистемологии, что присваивает философии как форме духовной культуры общества статус неопределенности, оспаривает ее уникальность и самоценность. В статье предлагается попытка анализа философского лирического произведения в русле феноменологии. Спорным остается вопрос научной разработанности проблемы. Уникальности философской лирики посвящена статья М. Эпштейна «О философских чувствах и действиях» [4]. Т. Штец исследует тему «Русская философская поэзия рубежа XIX-XX вв. как культурно-историческая рефлексия национального мировоззрения». Философская лирика изучается как литературное явление В. Базановым, А. Михайловым, А. Павловским. Философский контекст поэтических произведений рассматривается в работах В. Бибихина, А. Новикова.

Особо следует отметить польского феноменолога Р. Ингардена, ученика Э. Гуссерля. В работе «Исследования по эстетике» он предлагает феноменологический анализ лирического произведения на примере стихотворения Мицкевича

${ }^{1}$ Аристотель. Никомахова этика. VI, 7, 1141 b 2-8. 
«Аккерманские степи». Ингарден приходит к выводу, что любое произведение литературы двумерно по своей природе, т. е. имеет как вертикальную, так и горизонтальную структуру. Читатель воспринимает текст по вертикали, двигаясь от фонемьк кексеме, а затем к виду, т. е. конкретному зримому содержанию образа, который «обусловливается и определяется как особенностями наблюдаемого предмета, так и обстоятельствами, при которых имеет место наблюдение, и, наконец, психофизическими особенностями наблюдающего субъекта» [5, с. 10]. По горизонтали произведение характеризуется интенциональностью, онтологическими пустотами, конкретизацией, точками сборки. Феноменологический метод анализа философской лирики кажется оправданным, т. к. он обогащает восприятие текста, позволяет прочувствовать грань между объективностью и субъективным восприятием, конструированием собственного «жизненного мира» произведения. Он включает в себя анализ явления со всех сторон: с позиций прошлого, т.е. истории возникновения, смыслов и значений, формы и структуры, видов и типов проявления и функционирования, в аспекте связей с другими и взаимного влияния их друг на друга. Феноменологический анализ «раскладывает» на составные части то, что свободно проявляется, существует, самоопределяется.

Рассмотрим лирическое произведение А. Блока «Девушка пела в церковном хоре», используя феноменологический подход. Прежде всего здесь, как и в любом другом литературном произведении, очевидна двумерная структура. С одной стороны, читатель движется от первого слова к заключительному, слово за словом, строка за строкой, с другой - в каждом фрагменте обнаруживается определенное число компонентов, разрозненных, но вместе с тем связанных между собой. То есть в одном измерении читатель наблюдает смену фаз - частей произведения, в другом воспринимает одновременно множество компонентов - слоев. Первый «слышимый» слой — фоника. Произведение написано дольником - это вид тонического стиха, в единицах которого совпадает только число ударных слогов, безударные же слоги являются величиной переменной или могут отсутствовать совсем. В данном произведении дольник создает особый индивидуальный ритм, к которому добавляется аллитерация «n», «л», «б». «...белое платье $n$ ело в луче...». Звуковой поток создает музыку стихотворения. Лексический пласт захватывает читателя зримыми образами и буквально затягивает в пространство произведения. Основные слова-символы, слова-пустоты: девушка, церковь, белое платье, корабли, луч, радость, ребенок. Блок однажды признался, что всякое стихотворение - покрывало, растянутое на остриях нескольких слов. Покрывало и есть пространство для вида, для конкретизации символа, конструирования жизненного мира. Символизм языка дает ощущение бесконечной перспективы, сближения земного и небесного, временного и вечного.

Девушка пела в церковном хоре

О всех усталых в чужом краю,

О всех кораблях, ушедших в море,

О всех забывших радость свою... 
Троекратное повторение, градация чувства, эпитетов, мольбы о заступничестве за всех мореплавателей, путешественников зарождают образы дали, странничества, бесприютности, что усиливается противопоставлением (чужом краю - радость свою). Отдельные образы, органично соединяясь друг с другом, образуют самостоятельный смысловой слой. Далее в тексте напряжение нарастает, усиливается антитеза земное - небесное, мрак - белое платье в луче, летящий в вышину купола голос. Песня небесной чистоты и благости, радости и покоя. И вместе с тем казалось...

Анализ может быть продолжен в двух направлениях. Можно рассматривать произведение в контексте эпохи, вспомнить дату написания, обнаружить, что тем эмоциональным потрясением, что породило гениальный отклик, стало поражение русской эскадры в Цусимском сражении. Становится понятно, что пение девушки - несбывшаяся мечта, бесплотная надежда, которая спасительным щитом неведения отделяет от истины, боли, смерти. Поэтому здесь и сейчас плачет ребенок, всеведущий Спаситель знает, что ушедшим не вернуться. Плачет высоко, y Царских врат, что может указывать на вход в алтарь православного храма или быть аллюзией к Небесному царству.

Также можно попытаться осуществить феноменологическую редукцию, вынося «за скобки восприятия» слои культурного опыта в отношении текста. Начальной стадией в таком случае выступает эпохе. Н. В. Мотрошилова так описывает воздержание от суждения: «я “становлюсь незаинтересованным наблюдателем моего здесь-бытия и моего собственного Я”, становлюсь “феноменологизирующим Я”, раскрывающим “актовую жизнь" сознания» [6]. Следует, насколько возможно, нейтрализовать свои знания о тексте, о статусе его реальности, предпосылках его создания и, проанализировав первичное восприятие слоев, максимально прозрачно выразить первичные данные опыта.

Ранее автор уже рассматривал феноменологию объективности на примере формальной логики [7]. В этой работе феноменология раскрывается в своей естественной среде жизненного мира, интенциональности и конститутивности. Это глубоко интерсубъективные понятия, дополняющие стремление Гуссерля к строгому описанию сознания. Феноменологический маршрут проходит не только по аналитической стороне. Субъективность коррелирует с переживаниями, эмпатией. «Чистое я» трансцендентальной феноменологии - это предельная философская сингулярность и глубинная онтология одновременно. Субъект предоставляет широкие возможности и для проблематики конститутивной эпистемологии в том числе.

Гуссерль начал проект феноменологии из-за кризиса европейских наук, ограниченности классической рациональности, однако кризис субъективного плана внеисторичен, он сопровождает коллективные и индивидуальные субъекты с момента появления самосознания у сапиентных существ. Сегодня мы воспринимаем философию как науку, однако философия - это не только процесс рационализации и концептуализации, это еще и способ работы со слоями субъективных переживаний. Психологию, зародившуюся в недрах философии, постигла та же участь, что и иные эволюты философского знания - экономику, 
социологию, политологию, - они трансформировались в математизированные позитивистские дисциплины с минимальной возможностью учета фактора сознания.

Изучение образного мира сознания приобретает особую значимость в современной медиакультуре инстаграма, составившего конкуренцию культуре текста, которую предлагали «старые» социальные сети. Философия - это культура «long read», за многие века она отработала технологию создания сложных текстов для долгого чтения. Философ смотрит на мир как на текст. Однако скорость социальных изменений побеждает слоговое письмо, переводя смысловые структуры к практически иероглифическим мемам. Обилие информации так велико, что куда там до философских текстов, они последние в очереди. Не читают произведения литературы и журналистские статьи больше одной страницы. Современный человек, живущий в стрессовых ритмах, боится «толстой книги». Единицей информации вновь становится образ, а жизнь представляется хронотопической лентой мозаичных клипов и мемов.

Феноменологический инструментарий выступает когерентной процедурой исследования образной культуры. Многослойность — это исходная установка на множественность слоев и уровней восприятия объекта культуры. Тематизация одного из планов социокультурного объекта составляет процедуру конкретизации. Жизненный мир - экзистенциальная категория, фиксирующая субъективный план, актуализирующий социокультурное бытие с точки зрения релевантности внутреннему миру интересов, желаний, саморепрезентаций, жизненных стратегий, мотиваций и т. п. Существенно, что мы включены в жизненные миры других людей и образуем коллективные контексты релевантности [8]. Жизненные миры поддерживаются интенциональностью, направленностью сознания разных субъектов [9]. Миф, история, религия, наука, мораль, право репрезентируются в феноменологии как конститутивные смысловые структуры, создаваемые и поддерживаемыми коллективным сознанием [10].

Эпохе́, античное понятие скептиков, имеет неоднозначное значение для феноменологической процедуры [11]. Для Э. Гуссерля это была возможность устранить субъективность и прийти к чистому созерцанию, однако такое радикальное бракетирование оказалось не под силу не только его последователям, но и самому создателю феноменологии, переключившемуся на описание интерсубъективных интеракций и генерацию ценностно-смысловых структур. Таким образом, инспирированная натурализмом и объективизмом феноменология возвращается к субъективному миру. Этот дрейф не является проявлением усталости о мысли и вопрошания. Кризис системности - это естественная реакция на цифровизацию, оптимизацию, квалиметрию и прочие позитивистские инструменты. Феноменология в этом смысле ловко лавирует между физикой и лирикой, граммой и мемом, ration и emotio, техникой и жизнью, аполлоническим и дионисийским. Способна воспринимать сложные смешанные социокультурные объекты, реагировать их, преобразовывать в осознанные структуры, в смысловое напряжение и процессы жизненной адаптации. Обращение к философскому чувству как острому переживанию общекатегориальных вопросов обогатит понима- 
ние задач философского образования и задаст новые направления развития философии как интеллектуальной деятельности, направленной на отражение целостности и единства человека и мира.

\section{Литература}

1. Философия: энциклопедический словарь / под ред. А. А. Ивина. М.: Гардарики, 2004. URL: http://philosophy.niv.ru/doc/dictionary/encyclopedic/index.htm (дата обращения: 09.02.2021). Текст: электронный.

2. Рассел Б. История западной философии. М., 1954. 815 с.

3. Кант И. Соч.: в 6 т. М., 1965. Т. 1. С. 439.

4. Эпштейн М. О философских чувствах и действиях // Вопросы философии. 2014. № 7. С. 167-175.

5. Мотрошилова Н. В. Новая философская энциклопедия: в 4 т. / под ред. В. С. Степина. М.: Мысль, 2001. URL: https://iphlib.ru/library/collection/newphilenc/page/about (дата обращения: 17.02.2021). Текст: электронный.

6. Ингарден Р. Исследования по эстетике / пер. с польск. А. Ермилова и Б. Федорова. М.: Иностранная литература, 1962. 552 с.

7. Тимощук Е. А. Феноменология объективности // Вестник Бурятского государственного университета. 2019. № 4. С. 10-24.

8. Тимощук Е. А. Категория «жизненный мир» в социогуманитарном познании // «Адам әлемі» (Мир человека). 2014. № 1. С. 131-138.

9. Тимощук Е. А. Интенциональность и конкретизация как формы упорядочивания мира в феноменологии Р. Ингардена // Бренное и вечное: социальные ритуалы в мифологизированном пространстве современного мира: материалы всерос. науч. конф. (21-22 октября 2008 г.) / редкол. А. П. Донченко, А. А. Кузьмин, А. Г. Некита, С. А. Маленко; предисл. А. Г. Некита, С. А. Маленко; НовГУ им. Ярослава Мудрого. Великий Новгород, 2008. С. 334-337.

10. Тимощук Е. А. Конститутивность как ценностно-смысловой выбор // Ценности личности: сб. науч. тр. междунар. науч.-практ. семинара «Личность в современном мире: быть или казаться?» междунар. науч. конф. «Дулатовские чтения» ( г. Костанай, 11-12 апреля 2014 г.) / отв. ред. П. Ф. Дик; науч.-произв. журн. «Наука»; спец. выпуск. Костанай: Изд-во КИнЭУ, 2014. С. 278-283.

11. Тимощук Е. А. Феноменологическая редукция как фокус философии (сравнительный анализ западной и восточной философии) // Территория новых возможностей. Вестник Владивостокского государственного университета экономики и сервиса. 2014. № 1. C. 100-108.

Статья поступила в редакцию 19.11.2020; одобрена после рецензирования 08.02.2021; принята к публикациии 09.02.2021.

\section{PHENOMENOLOGICAL COMPREHENSION OF PHILOSOPHICAL LYRICS}

\section{Elena A. Timoshchuk}

Cand. Sci. (Philos.), A/Prof. of Social and Humanities Department,

Higher School of Public Administration,

Russian Presidential Academy of National Economy and Public Administration

82 Vernadskogo Prospect, Moscow 119571, Russia

e@timos.elcom.ru 
Abstract. It is traditionally believed that philosophy as an academic discipline tends to rationalize reality. However, many philosophical issues go beyond rational cognition. Various philosophical concepts develop from the emotional upheaval, sharp experience, feeling of certain moments of life. Such are the philosophical rubaiyats by Omar Khayyam, Goethe's poetry, Dostoevsky's works, Nietzsche's essays. In the era of strict rationalization of everyday life, scientometric requirements to the humanities, it is reasonable to enrich the teaching of philosophy with an aesthetic component, namely, philosophical lyrics. Phenomenological tools (layering, intentionality, epoché, life world) allow comprehending the works, taking out of perception the layers of cultural experience. Turning to a philosophical feeling as a sharp experience of category-wide questions will complement the teaching of philosophy, and the phenomenological method of analyzing lyric texts will help develop a personal perception of philosophical problems.

Keywords: philosophical lyrics; feeling; subject of philosophy; phenomenological method; layering; epoché.

\section{For citation}

Timoshchuk E. A. Phenomenological Comprehension of Philosophical Lyrics. Bulletin of Buryat State University. Philisophy. 2021; 1: 64-70 (In Russ.).

The article was submitted 19.11.2020; approved after reviewing 08.02.2021; accepted for publication 09.02.2021. 